\title{
brazilianpoliticalsciencereview
}

\author{
REVIEW ESSAY
}

\section{Taking Stock (with discomfort) of the Military Dictatorship Fifty Years after the 1964 Coup: a Bibliographical Essay*}

\author{
Maria Celina D'Araujo \\ Pontifícia Universidade Católica do Rio de Janeiro, Brazil
}

This essay reviews the main analyses produced for publication in 2014 alluding to the 50 th anniversary of the 1964 coup and the dictatorship that followed (1964-85). It is noteworthy that most of these analyses, authored by historians and journalists, relativize several Manichaean concepts and versions; chiefly, they enhance society's responsibility for this authoritarian experiment. The coup, they claim, was not an atypical event in the country's political history; it simply expanded conservative and authoritarian values. In daring fashion, they point out the precarious or absent democratic vocation of the forces of the Left, as well as the advances in terms of the country's economic and social modernization under the military governments. The duration of the dictatorship is also questioned. In the eyes of some, it lasted only from 1964 to 1979, and arguments to this end are exhaustively presented. The fact that the report of the National Truth Commission (NTC) was released also in 2014 raised an intense debate in the press and in academia about repression and the crimes of the dictatorship, especially against urban guerrilla organizations, which are also examined in instigating fashion in this bibliography.

Keywords: Brazil; 1964 military coup; memory; civil society; dictatorship. 
he 1964 coup was a milestone in the country's history, particularly for political science. The political regime changed and launched persecutory and discretionary initiatives. Academia and the Left questioned their own wisdom, unable as they were to forecast - or even perhaps to understand what was going on.

In Brazil but also at advanced research centres in Europe and the United States, political scientists pored over this and similar events, thus inaugurating a vast array of pioneering studies about democracies in crisis, authoritarianism, new authoritarianism, the military, development, capitalism and politics in developing countries etc. Studies coordinated by Juan Linz, Alfred Stepan, Philippe Schmitter, Guillermo O'Donnell and others lent new airs to political science as a discipline capable of creating innovative analyses and constructing models, even if $a$ posteriori, to understand the fragile stability of Latin American and South European democracies. Equally, the exhaustion of these dictatorial experiments gave rise to studies on the crisis of dictatorships and processes of democratic transition, consolidation or stabilization. The delicate question of how democracies are born, die and are reborn occupied plenty of academic minds in the political science field during the 1970s and 1980s. These decades were especially rich for studies in comparative politics.

With the rebirth of democracy in Brazil, political science prioritized the study of political institutions, including themes like political parties, the Legislative, elections, the federative pact, public policies, inequalities and others.

On the $50^{\text {th }}$ anniversary of the 1964 coup, several universities, research institutions and public bodies held seminars all over the country always with surprisingly large audiences. The question particularly mobilized youth, perhaps more disquieted since the mass demonstrations of 2013. Turnout was high at the activities organized to this end, with audiovisual versions, films and documentaries. The date was exhaustively remembered also in the mainstream press, with the publication of articles by top writers and intellectuals from various fields ${ }^{1}$. Without being simplistically optimistic, one might say that there was

\footnotetext{
${ }^{1}$ An examination of such press materials would provide a good indication of how this dramatic moment was reinterpreted and reconfigured in comparison with what was said
} 
interest from several sectors in touching on a subject normally restricted to a minute circle of intellectuals who do not exactly tend to be reader-friendly.

The fact that this $50^{\text {th }}$ anniversary coincided with the last year of the work of the National Truth Commission motivated the publication of breaking news stories with new findings about the period brought to light not just by the NTC but also by investigative journalists ${ }^{2}$.

In general, these pieces innovated in many regards. They publicized the names and biographies of torturers, the locations of clandestine prisons and torture chambers, and the actions of anti-dictatorship lawyers and (not few) military personnel ${ }^{3}$. They also dared to question more explicitly than before the democratic credentials of much of the Left that fought the dictatorship, drawing attention to the fact that authoritarianism and scant zeal for the legal rules of the political game were features common to left- and right-wing groups.

These are not new themes when one looks at the period, but the dimension and emphasis given to them were altered in the midst of the ideological debate resulting from the creation and work of the NTC.

From the point of view of academic production in the strict sense and of memoir-type publications by politicians and journalists, a few dozen books and numerous articles came to light to reminisce and at times to reinterpret the meaning of the coup and the contents of the military governments (1964-85). The focus here is on some of these books published in 20144. Historians were the

in 1994 and 2004, for instance (already under democratic rule); a good theme for theses and dissertations.

2 The NTC was charged with looking into serious crimes against human rights committed by state agencies from 1946 to 1988. These two time limits have to do with the promulgation of the country's first democratic Constitution (which continued in force during the first four years of the dictatorship, though coexisting with authoritarian measures) in 1946 and the current Constitution, promulgated in 1988. Between 1946 and 1964, there occurred 11 deaths for political reasons, especially in the countryside. The total number of deaths and disappearances for political reasons between 1946 and 1988 was 434, according to the NTC's 2014 report. Of these, 191 people were killed and 143 were forcibly disappeared. Most took place during the years of more intense repression (1969-74): 98 deaths and 170 disappearances. See, http://www.cnv.gov.br/images/relatorio_final/Relatorio_Final_CNV_Volume_I_Tomo_I.pdf ${ }^{3}$ According to the NTC report, 6591 members of the armed forces or the police were affected by exceptional measures for disagreeing, to one extent or another, with government directives or with their commanders.

4 Twelve were selected: Chagas (2014); Ferreira and Gomes (2014); Fico (2014); Markun (2014); Motta (2014a); Napolitano (2014); Reis (2014a, 2014b); Reis, Ridenti and Motta 
academics that devoted themselves most to the subject. Few political scientists and sociologists took on the task of reviewing the impact of this event for the Brazilian political system or for the social sciences.

According to this literature, three points are noteworthy: the civilian character of the coup and society's consent for it to occur; questions surrounding the idea of military dictatorship, how long it lasted, when it began and even whether it existed; and the role of the armed opposition.

In this intellectual production, there predominate questions about the absence of resistance to the coup and about the initial and final milestones of the military's dictatorial experiment in power, i.e., when in fact the military dictatorship began and ended. Did the dictatorship begin with the 1964 coup or with Institutional Act Number 5 (AI-5) in 1968? Did it end with the 1979 amnesty or with the exit of the last general from power in 1985? What should the periodization of the 21 years of military governments look like? What were the impacts of these governments on the modernization of the country? To what extent can one understand the armed struggle against the regime as a demand for democracy?

These questions touch upon an ever more sensitive point: the dimension of the responsibility of society, and even of the opposition, in the consummation of this dramatic event (1964) and of the maintenance of the military in power. Despite many disagreements, there are convergences vis-à-vis accepting that both the coup and the dictatorship were the work of civilians and the military, although the emphasis placed on each may differ.

Another common feature is their use of "military regime" as a synonym for "military dictatorship". Conceptually, regimes are democratic, authoritarian or totalitarian regardless of the clothes or institutional affiliation of those who rule. The bibliography in question maintains this synonymy, and such conceptual license has not been questioned. The expression that has been coined in recent years and ratified at the $50^{\text {th }}$ anniversary is "civilian-military" dictatorship or (Motta (2014b) and Ridenti (2014)) and one article in a periodical (Carvalho (2014)) were chosen. 
regime, thus categorically pointing out the political responsibility of non-military people for state policies in this period.

\section{A coup with no resistance}

If in the heat of the moment, political science's key concern was to understand the reasons for the coup; fifty years later, the chief motivation, especially for historians, is finding plausible explanations for the absence of a reaction. Political science analysed the coup using explanations that took into account: the economic crisis; problems of political representativeness and institutionality; the Cold War; ideological radicalization; daring demands for basic reforms; the crisis of populism; modernization theories; conservative fears of the advance of labour and peasant movements; the need for modernization of industrial capitalism; the emergence of the Authoritarian Bureaucratic State (ABS); imperialism; the autonomy of the military; the alliance of the military with the bourgeoisie; the country's structural dependence; the need to obstruct social demands for capitalism to be able to modernize; external influence (i.e., the United States); the decision-making paralysis that came over Congress; the inability of the Left to reach a common denominator vis-à-vis the reforms; the exhaustion of the national developmentalist project; the interests of multinationals and their local partners; and so on and so forth. The objective was to arrive at the most explanatory variable for the crisis of democracy and the formation of a new type of authoritarianism among us, i.e., a military dictatorship.

In the end, these explanations can be grouped in one of two ways: those that emphasise economic questions and those that emphasise political questions. In the midst of all this, there emerged an innovative literature that sought to examine the specificity of the military institution and to what extent it could be reduced to the social and economic interests of a class. Organizational analyses of the armed forces gained strength, particularly those that lent significant weight to the aspects of military discipline and hierarchy, i.e., to the organizational ethos of the military institution ${ }^{5}$.

5 The most important pioneering work on this subject is the book by Coelho(1976). 
The advances of democracy in 2014 with an emphasis on rights, on coexistence with political diversity and on social participation, help one understand why we worry so much about our democratic convictions and authoritarian traditions when we revisit this event. Incidentally, all over the world new studies have drawn attention to the responsibility of society - elites or not for the emergence and maintenance of authoritarian regimes ${ }^{6}$.

For instance, Carlos Fico (2014), the historian who wrote the most about the coup and the dictatorship, and Flávio Tavares (2014), journalist, writer and eye witness of the facts of March and April 1964, show with abundant data how Congress was the plotters' chief ally during the final moments of the democracy the country had been building since 1946. Tavares (2014) reports how in the early hours of April 2, the speaker of the National Congress, Senator Auro de Moura Andrade, gathered 183 federal deputies (out of a total of 404) and 29 senators (out of a total of 60 ) to convey the message that the presidency was empty, although a note from the presidency itself, read out at the occasion, stated that the president had gone to Porto Alegre, was fully exercising his office and was preparing the resistance. However, there prevailed the understanding that leaving Brasília meant abandoning the government and the presidency was declared empty, a parliamentary decision made without any debate, in just three minutes. Next, the speaker of the Chamber of Deputies (lower house of Congress), Ranieri Mazzilli, was declared president (MARKUN, 2014, p.147). In order to prevent debates, Senator Andrade, had the microphones and lights of the house switched off.

Minutes later, using the back door and flanked by the chief justice of the Federal Supreme Court (STF), the speaker of Congress and a general who carried out bureaucratic duties and had been called upon hurriedly, Deputy Mazzilli entered the presidential palace (Palácio do Planalto) to be sworn into office in a candlelit room, until someone could be found who knew how to turn on the palace lights.

All of this bizarre transfer of office was accompanied by a secretary from the US embassy by the name of Robert Bentley. In an interview to Fico (2014), he stated:

${ }^{6}$ An example of this is the three-volume compilation edited by Rollemberg and Quadrat (2010). 
(...) at 3am, the parliamentarians gathered outside the Congress building for the short walk to the Planalto presidential palace. The chosen president, Mazzilli, was taken to the palace in a car literally covered in armed men. The solemn procession of congress people was barred at the presidential palace by apprehensive guards carrying machine guns who did not know what was going on (FICO, 2014, pp. 85,86).

The parliamentarians convinced the guards to let them enter the palace. At 3.30am on April 2, Mazzilli took office. According to Bentley, the "finishing touch had been put on the coup d'état" (FICO, 2014:86).

Symptomatically, while in Brasília Congress improvised apparently legal and constitutional rites for the transfer of power, in Rio de Janeiro, General Costa e Silva, the longest-serving general in the Army and the one with the most prestige among young, radically anticommunist officers, declared himself chief of the Command of the Revolution. Since the "revolution" was the highest objective of the victors of those days, whoever commanded the "revolution" commanded the country, under the thinly veiled fantasy of an active legislative branch of government.

Hours after Mazzilli was sworn in, the US government recognized the new president, even though Goulart was still in the country. In the words of Tavares (2014), "Congress had staged the coup and formalized the toppling [of the president] before the military themselves"(TAVARES, 2014, p.212). Days later, a group of eight politicians, six from the UDN and two from the PSD (Martins Rodrigues and Ulysses Guimarães) presented a draft institutional act proposing to take away the political rights of deputies considered subversive for 15 years (MARKUN, 2014, p. 167).

Fico (2014) is among those who wonder how the coup was possible, why so many people supported it and why the coup became a military dictatorship. In his eyes, "one must bear in mind that it was not an initiative by rash military men" (FICO, 2014, p. 07). Many who supported the coup early on, became critics of the dictatorship after it was a fait accompli. Carlos Fico is one of the authors who devoted most effort to studying US participation in the coup. In previous works, as in the 2014 book, he stresses that Operation Brother Sam was requested by the Brazilian military, as opposed to the version maintained for a long time. Brazilian politicians and military personnel and US diplomats created a scheme for military 
aid and energy logistics by the United States in case there was a reaction to Jango's unseating; since there wasn't, the help was not needed. Even so, the expenditures were made and the US government tried to have them reimbursed. "In other words, Brazil almost paid to be invaded" (FICO, 2014, p. 80).

The institutional act that came about on April 9, removed the political rights and terms of office of hundreds of politicians, military personnel and trade unionists for ten years. On April 11, Castelo Branco was elected with the votes of important PSD congressional leaders like Franco Montoro, Juscelino Kubitschek, Ulysses Guimarães and Nelson Carneiro.

The examples of collaboration by the political class and society generally with the success of the coup are recalled in the bibliography in question, as is the role of the Church and press. The initiatives of the Women's Campaign for Democracy (CAMDE), with its anticommunist demonstrations, were in line with the concerns voiced in the mainstream press about the country's political uncertainties ${ }^{7}$.

Goulart decided to head for Montevideo on April 4, knowing that the United States would support the plotters in case of a reaction and realizing that no significant front of politicians or military men had been formed in his favour.

All the authors agree that Congress acted ahead of the president's resignation, declared the presidency to be empty and facilitated the military's path to power along tortuous routes that nevertheless alleged constitutional bases. Goulart's exit and the arrival days later of an unelected military man at the presidency took place inside a National Congress that was indeed partly coerced, but according to these sources also largely relieved by the closure given to the political crisis.

The military's concern with institutional formalities in this whole process is highlighted by Chagas (2014), when he carefully details how the leadership struggle between Costa e Silva and Castelo Branco was overcome - such concern was the key motivating factor.

The coup was crowned in Congress by means of a vote for a new, military president. It was not by chance that the first "legal" text passed by the new

7 Silva (2014) is among those works that draw attention to the responsibility of the mainstream press for the success of the coup and the dictatorship. 
government was called Institutional Act. The institutionalization of the regime was a formality pursued obsessively.

Reis (2014a) joins the chorus of those intrigued by the fact that the civilian-military movement of 1964 , as he terms it, was not immediately challenged:

What surprised contemporaries was the ease with which Jango was toppled and the plotters prevailed. As far as prevailing interpretations are concerned, the forces of the right won because they were more powerful and organized. Meanwhile, the forces of the left, disorganized, incapable of fighting, were strong only in terms of their discourse. All that remained for them, converted as they were into victims, was defeat (REIS, 2014a, p. 82).

The coup is depicted as a political conflict between two broad ideological currents - forces of the Left and Right - that nonetheless had internal ambiguities. In the author's eyes, the ideological radicalization paved the way for the coup. In this radicalized dispute, the victor was the side with more power of initiative. The forces of the Left were paralysed. There was "a complete absence of resolve, of which the clearest expression was Jango's behaviour". Thus, the unlikely prevailed: "the plotters' victory without a fight" (REIS, 2014a, pp. 84,85).

Ferreira and Gomes (2014) reconstitute the João Goulart government (1961-1964) with acuity. Although they do not espouse a theoretical or analytical view of the reasons for the coup, they are guided by the idea that it was not the product of exclusively military planning, or even of detailed planning by civilians or the many other groups that made up the political scenario at the time, whether within parliament and the political parties or the Armed Forces. Equally, they ask themselves the question that has been present in all reflections on the lack of reaction and why it was that those who wanted to react were abandoned by the president's dispositivo militar ("military device") or by Brizola's Group of Eleven ${ }^{8}$. Like many other works, they refute Manichaean arguments about the

\footnotetext{
${ }^{8}$ Groups announced by Leonel Brizola, on a mission to preach anti-imperialist ideology in October 1963, over which there were doubts as to whether they were armed or not. His aim was to "consolidate and cement the unity of the popular and progressive forces of nationalists, civilians and the military, and of all Getulista and labour groups that consider themselves summoned by Vargas' letter"(MARKUN, 2014, p. 105, quoting Mariza Tavarez).
} 
omnipresence of the United States in the opposition and in the gorilas' military action.

José Murilo de Carvalho (2014), a young university student in the state of Minas Gerais when the coup broke out, still remembers the feeling of impotence and perplexity that took over him at the time. In the article titled "Fortuna e virtu no golpe de 1964", published in a special edition of journal Estudos Avançados on the 50th anniversary of the coup, he reveals how the facts unfolded before his eyes, in real time, without there being the possibility of a reaction.

An important witness account from those hectic, utopian, transgressing and intolerant years can be found in José Serra's (2014) book. In it, two important theses are stated: that Jango understood that he would not be able to see his term of office through to the end, as opposition to the government grew with each day that passed among left-wing groups, liberals, conservatives and in the barracks. In addition, like many actors of the time, Jango himself understood that this would be just another coup and that there would be a "PSDization" of the new government 9 . The radicalization of the new government took place quickly, however, guaranteeing the hegemony of the more radical sectors, that is, the anti-communist ones $^{10}$. The book is also another contribution to the remembrance of Brazilian political exiles who crossed seas and faced perils and deprivation in order to remain alive.

In the same memorialist vein, journalist Carlos Chagas (2014) recalls that the lack of mobilization surrounding the coup demonstrates a structural element of the country:

\footnotetext{
9 The notion that the coup would lead to a "PSDization" of the government was held by many observers at the time and shared by one of the most famous books on the period, the polemical Quem dará o golpe no Brasil [Who will stage the coup in Brazil?] (SANTOS, 1962). On the other hand, the account of one of the most important leaders of the PSD, Amaral Peixoto, is spot on in its description of the other side of the story, that of the uncertainty of those staging the coup: "We were still imagining what that revolution would be like, we didn't have the faintest idea. In fact, neither did the revolutionaries; I found that out later. Castelo and Costa e Silva had no idea, they didn't know whether to close down Congress, depose the governors, instate a new regime or if it was to be a deposition of the Brazilian president, pure and simple, with Mazzilli taking over government (...) I sensed the same in everyone: a profound lack of definition. They had staged a revolution but nobody knew how far it would go" (CAMARGO, 1986, p. 469).

10 Needless to say, communism and anticommunism were overblown concepts in the context of political radicalization of the time.
} 
The elites were running the show and had the complete backing of the media. And, much as in countless other episodes, starting with Getúlio's death, the masses, with the exception of a few union leaders, remained amorphous, neutral and complacent as long as news was not broken to them that their salaries were being frozen and their labour rights removed - something that was not to take long (CHAGAS, 2014, p.50).

With this perception of the "masses", the impossibility of a reaction is explained.

Napolitano (2014) begins his excellent book by listing a number of questions similar to the ones that guide this text and show up in debates on the coup and the dictatorship, but he does not specifically spend time on this aspect of the absence of reaction. His thesis is that the coup was the product "of a profound division in Brazilian society, marked by a clash between two different projects" in the context of the Cold War (NAPOLITANO, 2014, p. 10). However, the book does devote itself to innovative explanations for understanding why the defeated side did not react. As a result, concerned with annihilating communism, the victors did away with all likelihood of reform. For Napolitano (2014), differently from the interventions of 1945 and 1954, the 1964 coup was a coup against a regime, not just against a government (NAPOLITANO, 2014, p. 67), as the winning civilmilitary coalition had two clear objectives: to destroy the intellectual elite and reformist policy and to cut the "organizing ties between this elite and grassroots social movements" (NAPOLITANO, 2014, p. 70). Although the plotters thought that it would be another "sanitizing" act of Brazilian politics, the unanticipated effect was the implementation of a dictatorship at the hands of the military.

Regardless of the reasons for the absence of reaction, for Reis, Ridenti and Motta (2014), the "project for a Republic was lost in 1964. The programme of socalled 'base reforms', a nationalist programme based on the State playing a key role alongside the working classes of the cities and countryside, experienced a strange defeat, exiting the stage without a fight" (REIS, RIDENTI AND MOTTA, 2014, p.11).

\section{The regime's support}

Napolitano (2014, p. 11) sustains that in spite of wide social support for the coup, the government that ensued could not be called a civil-military dictatorship because it was the military who were at the centre of the decision- 
making process throughout the entire period. To Reis (2014b), the dictatorship's success (1964-1979) was not only owed to the support it had from entrepreneurs, multinationals and conservative sectors. Workers and the public sector also gave the regime legitimacy and obtained gains from it, whether material or symbolic. Among the public servants of large state-owned companies or mixed-ownership companies, or among those who occupied the islands of excellence of high public administration, there seemed to be pride in belonging to the great agencies at the centre of the country's planning and development, which paid them up to 16 monthly salaries a year. Equally, according to the author, the workers' silence cannot be attributed only to the repression. The dictatorship increased inequality but reduced poverty and gave job opportunities to a large stratum of independent workers and qualified blue-collar workers. The so-called leaden years, the harder years of political repression, were also, according to the author, golden years in terms of employment, opportunities for increasing growth, opening of borders, social mobility and cultural effervescence (REIS, 2014b, p. 88,90).

Among the books that deal with the economic modernization along conservative and authoritarian lines that took place during this period, Motta's work (2014a) is an essential and pioneering one. According to him, relations between universities and the military regime were ambiguous. Many Brazilian universities were marked by an intense student movement of political, social and cultural dimensions. They had all the ingredients to be the new regime's mortal enemies, particularly because many members of teaching bodies held ideological positions that were more to the Left. However, the author recalls that there was also a right-wing and even an anti-communist student movement and that many lecturers spontaneously collaborated with the government. Relations between the government and universities were marked by tensions, conflict, co-optation and accommodation and were therefore far from binary or a case of "resistance versus collaboration" (MOTTA, 2014a, p. 13). According to the author, this goes back to our conciliatory tradition, especially prominent among the elites. Here we are referring to an intellectual elite, which mostly overlaps with economic and cultural elites and with the military elites, which, their social extraction aside, were the elites in power. 
Motta (2014a) recalls that unlike Argentina and Chile, for example, the Brazilian dictatorship opted for economic modernization along industrial lines and for that, science and technology were vital. It was the military governments that drove forward the postgraduate system in Brazil, making it one of the few developing countries to possess an actual academic network encompassing all areas of knowledge, including social subjects. They were also responsible for the university reform, copying other countries' models. In some cases, academics sympathetic to the Communist Party were even hired or remained in their jobs. The "witch hunt" in universities was a fact. Many lost their jobs, numerous students were expelled, but the fact is that there is another side to this story, the side in which the regime had much to gain from knowledge production and academics obtained funding for research. The creation of the FINEP (Studies and Projects Financing Agency), for example, was a crucial initiative for developing the sciences in the country and some academics banned from their professions worked at FINEP or other institutions, earning their wages via agreements with third-party institutions. Likewise, other research centres such as the CEBRAP (Brazilian Centre for Analysis and Planning), composed of and directed by banned academics forbidden from receiving direct funding, ended up receiving funding by means of artifices negotiated within the elite itself.

What the author highlights is that relations between academia and the government were not only marked by the persecution, expulsion and arrest of lecturers and students. There were also mutual gains. More than that, in cultural terms, hegemony was in the hands of university intellectuals, not of the government. This is no doubt a polemical and courageous book, balanced and lucid, which insightfully shows pragmatic nuances and how strategic interests linked groups that dominated important spheres, whether in politics, the military or the field of knowledge.

The country's modernization is the main theme of the book Modernização, ditadura de democracia, edited by Daniel Aarão Reis (2014a) and containing an article by the editor himself on Brazilian politics in the 1960s-2000s. With contributions by other authors, the publication revolves around the process of change the country underwent politically, culturally and economically during these decades. In the book, Reis (2014a) does not reinterpret the meaning of or reasons 
for the coup, but attempts to discuss the legacy of the dictatorship, avoiding "simplified or reductionist interpretations", focusing instead on the thesis that dictatorships must be regarded as acts of social construction: "dictatorships have just been moments of a larger history whose strong links to the past and the future are not hard to make evident"(REIS, 2014a, p.26). According to him, the dictatorship was implemented without one gunshot and drew to a close without one blow. It was instated and survived thanks to the protective mantle of authoritarianism and the elitist pact existent in Brazilian society. In the same way, Villa (2014) recalls that authoritarianism in Brazil "is part of a solidly rooted antidemocratic tradition that was born with Positivism at the end of the Empire. Contempt for democracy is a spectre that has haunted our country during the 100 years of the Republic" (VILLA, 2014, p. 10).

Also focusing on the idea of modernization, sociologist Ridenti (2014) recalls that the government disseminated the idea that only with strong governments could there be economic progress: "The regime's legitimization was based on its successful modernization, which also involved social welfare measures". Whether this was due to an a priori calculation or well-planned circumstances, the fact is that "since 1964 a project of modernization of Brazilian society was gradually constituted with economic and political measures taken by the authoritarian State, associated with private enterprise, which came to be known as a conservative modernization"(RIDENTI, 2014, p. 37). By the end of this process (RIDENTI, 2014), "the bases for the consolidation of bourgeois hegemony in Brazil were established". The capitalist organization of society became natural from then on. In this sense, "the regime implemented in 1964 was the crowning of a long process of bourgeois revolution in Brazil on authoritarian bases". According to the author, in a future in which the capitalist order is consolidated, this view could lead to the adoption of "nuanced versions" of the use of force "during the military regime, highlighting its modernizing aspect, considered positive in itself"(RIDENTI, 2014, p.46).

Renato Ortiz (2014) is another author who draws attention to society's modernization and the cultural scenario after 1964. Indeed, Brazil did not switch into reverse as the Argentina of the military, but nothing indicates that this 
modernization might not have occurred or even been more intense under democracy. In fact, regarding this, he recalls that the cultural effervescence of the early years of the dictatorship "began in the late 1950s, with Bossa Nova, the Cinema Novo, Teatro de Arena, the CPC da UNE (Popular Culture Centre of the National Union of Students), intellectuals of the ISEB (Superior Institute of Brazilian Studies) and people's cultural movements in Recife"(ORTIZ, 2014, p.123). These movements persisted in spite of the onslaught by the military regime.

\section{Cultural timeframes of the dictatorship and guerrilla}

Although civilian responsibility for the coup and dictatorship is emphasised in the totality of this literature, there is no consensus regarding the beginning and end of this political experiment. For most, however, it began in 1964 with the civil-military coup and ended in 1985 with the exit of the last general from the Presidency.

Attention must be paid to the fact that this dispute about timeframes is not only related to a desire for polemics or innovation but to what today is understood by dictatorship and democracy - certainly an important point for Brazil today, having gone through the experience of Workers' Party governments ${ }^{11}$.

Certain authors such as Chagas (2014) and Napolitano (2014) adopt the most current chronology. An initial period might span 1964 to 1968, when the most repressive period began, which lasted until 1979. After that, came the transition, which ended with power being transferred to a civil government. Napolitano, a historian working in the field of culture, dedicates much space to the discussion on the extent to which cultural transformations were possible in spite of the dictatorship and how much they contributed to delegitimizing it.

Reis (2014a) is one of the authors who reject the timeframes established by the classical literature on the military governments. In brief, this literature identifies three periods: the Castelo Branco government, the leaden years (Costa e Silva and Médici) and the transition years (Geisel and Figueiredo). Although it is not the first time that this chronology is questioned, it was in 2014 that its validity was more intensely challenged. For Reis (2014a), the dictatorship started in 1964

\footnotetext{
${ }^{11}$ A good collection of articles on this period is the one by Gallo and Rubbert (2014).
} 
and ended in 1979, when it passed the Amnesty Law and the party reform Institutional Act No. 5 having been revoked in 1978. Thus, "the dictatorship existed in Brazil until early 1979, when the institutional acts through which the country's legal order was made and remade were revoked" (REIS, 2014a, p. 103).

For Villa (2014), too, "the military regime was not a 21-year dictatorship. It is not possible to call the period 1964-1968 (up until the AI-5) a dictatorship, with all the politico-cultural upheaval there was in the country, let alone the years from 1979-1985, which saw the Amnesty Law approved and direct state government elections in 1982"(VILLA, 2014, p. 11). Even recognizing that in this initial period "the regime was unforgiving with all types of opposition" and that it sought a "legal façade", the author (VILLA, 2014, p. 87) maintains that the dictatorship only began in 1969. In the previous years, from 1964-1968, there were elections (although limited), Congress, functioning state Legislative Assemblies and Municipal Chambers, intense cultural activities in drama, music, poetry and the fine arts, as well as powerful behavioural changes among the young, especially with regard to dealing with authority, much in the same way as in the rest of the world.

In the same way, for the author, the 1979 period cannot be considered a dictatorship because in spite of certain people remaining stripped of their political rights, there was the amnesty and freedom of the press was restored. Villa (2014) also recalls other well-known aspects - the singularities of the Brazilian military dictatorship that distinguish it from other similar experiences in neighbouring countries, among them, the fact that Brazil was governed by army generals who took turns in power, legitimized by indirect elections in Congress. This was different from what took place in Chile, for example, where only one general held power throughout an entire dictatorship (1973-1990).

In 2014, several authors stood out with their questioning of the role of the guerrilla during the dictatorship, among them Reis (2014b), Reis, Ridenti and Motta (2014) and Villa (2014), two historians with distinct ideological positions. For precisely that reason, it can be said that never before have authors dared to question the Left's contribution to fighting the dictatorship so much, or even, to 
think about responsibility for this initiative and its consequences, whether anticipated or not. Inexperienced and full of daring, for Reis (2014b):

...far from being the radically innovative forces they [the guerrillas] thought themselves to be, they were the final froth on the waves made by movements preceding 1964. Authoritarian and haughty, generous and audacious, bordering on arrogant, they mistook the moment in history and society - and paid with their existence, both physical and political, for the mistakes made and for wanting the revolution they loved so much, but which had definitely failed to come to them (REIS, 2014b, p. 78).

In the words of Villa (2014), the guerrilla did not result from resistance to the dictatorship:

...many of these groups existed before 1964 and others were created shortly after, when there was still the democratic space (it suffices to note the great cultural activity of the period 1964-1968). In other words, the option for the armed struggle and disregard for a political struggle and participation in the political system, and the sympathy for Guevarist foquismo preceded the AI-5 (December 1968), when the regime did in fact close down (VILLA, 2014, p.11).

In an even more conclusive fashion, he states that all the

armed struggle groups advocated socialism and the dictatorship of the proletariat. None of them, at any given moment, espoused democracy and a regime of full democratic freedoms. On the contrary, to speak of democracy was a petty-bourgeois diversion. Thus, all political and "mass" struggles were disregarded. It was precisely what the regime wanted (VILLA, 2014, p.382).

He follows this reasoning through by quoting passages of the 1969 Minimanual do guerrilheiro urbano by Carlos Marighella, which called for, among other actions, the physical extermination of the commanders and subordinates of the Armed Forces and police forces.

Also according to Ridenti (2014), left-wing groups active "before 1964, such as the Communist Party of Brazil (PC do B), People's Action (AP), the Revolutionary Marxist Workers' Political Organization (POLOP) and the nationalist left carried on in action after the coup, all of them susceptible to splits"(RIDENTI, 2014, p. 33) that produced various other groups during the dictatorship. Thus, over a short period the Brazilian left became a mosaic of dozens of small political organizations "that diverged regarding the characteristics of a left-wing revolution 
but that agreed on the idea of toppling the 'dictatorship' through the armed struggle"(RIDENTI, 2014, pp. 33,34) .

It is recognized that the military won the battle against the guerrilla but not the dispute over the memory of the dictatorship ${ }^{12}$. Still according to Villa (2014), this was what allowed "the groups to achieve hegemony in the construction of political memory. They transformed the defence of the proletariat into defence of democracy" (VILLA, 2014, p. 386). He concludes that the dictatorship's defeat was not related to left-wing struggles. The dictatorship did not fall because of the left's resistance. On the contrary, it was the left-wing guerrilla that fanned the dictatorship's flames.

For Napolitano (2014), the guerrilla "was born out of the impasses and dissent in the left caused by the military coup". He recognizes that there existed this type of intention before the coup, which "did not actually constitute an immediate and consistent political option able to enlist significant supporters and seduce a large part of the military" (NAPOLITANO, 2014, p. 122). According to him, the option for the guerrilla during the dictatorship derived from the assessment of the 1964 coup made by the Left. According to these assessments, the coup occurred due to João Goulart's conciliatory tone and the Communist Party's moderate position. Following this line of thought, it was therefore necessary to radicalize the opposition. The first armed reactions came from military personnel purged by the government under the leadership of Leonel Brizola and inspired by the Cuban revolution. Gathered between March and April 1967 at the Caparaó Peak on the border between the states of Minas Gerais and Espírito Santo, this group "ended up having all of its eight members arrested by a police patrol from Minas without firing so much as one gunshot" (NAPOLITANO, 2014, p. 123).

With a more reflexive analytical style, Ortiz (2014) also demonstrates his perplexity: "When revisiting the past, I cannot fail to contain my disappointment and point out at least one aspect that, in my view, prevents this compromised

12 This thesis has already been defended by D’Araujo, Castro and Soares (1994). 
memory from being refreshed: the topic of democracy. The forces of the left never held it in high regard"13 (ORTIZ, 2014, p.126).

Thus, we see that for several reasons a heroic version of the guerrilla cannot be found in the bibliography examined. In the same way, the social rejection of the government of the Armed Forces is not disregarded, neither is the fact that the military governments were always dictatorial admitted to.

\section{Open debate on the coup and the military dictatorship}

In this outline of the bibliography cited, certain aspects draw our attention. Firstly, paradigmatic authors or books whose interpretations are commonly used by all texts cannot be identified. Neither is there a predominant choice of any given theoretical model. What can be noticed, however, is a greater freedom of the authors to accept historical and conceptual revisions and to interpret acts and facts from the past. The Right versus Left debate remains dominant and the manner in which these currents are addressed is at times freer and at others more complex. As a larger result of all the important texts examined, some uncertainties and concerns remain. Among them is the doubt regarding whether or not the authoritarian bias is as structuring as some presume it to be, and whether liberal democracy or democratic socialism are impossible in Brazil. Equally, they provide more resources for dealing with the important polemics between politics and economic development.

Authoritarianism is a theoretical theme in political science and the empirical forms through which it is expressed are valuable resources for understanding authoritarianism in action. These writings are generous in that they question the values of our democracy and undo case-based reasoning for our retrogression or democratic deficits. No doubt they have all played and will play a crucial role in possible interpretations of the commitment of relevant political actors such as parties, Congress, the Armed Forces, business, the Church, universities, the press and others to the democratic Rule of Law, and particularly to the type of democracy we will be able to build.

13 On this, see D'Araujo (2015). In this publication, evidence is shown that many left-wing or progressive intellectuals considered representative democracy and Congress to be obstacles to development. 
Translated by Leandro Moura Submitted in January 2015 Accepted in July 2015

\section{References}

CAMARGO, Aspásia et alli (1986), Artes da política, diálogo com Amaral Peixoto. Rio de Janeiro: Nova Fronteira. 588p.

CARVALHO, José Murilo (2014), Fortuna e virtu no golpe de 1964. Special issue "50 anos do golpe de 1964". Estudos Avançados. Vol. 28, № 80, pp. 07-16, Jan/Apr. São Paulo.

CHAGAS, Carlos (2014), A ditadura militar e os golpes dentro do golpe, 1964-1969. São Paulo: Record. 490p.

COELHO, Edmundo Campos (1976), Em busca de identidade: o Exército e a política na sociedade brasileira. Rio de Janeiro: Forense. 207p.

Comissão Nacional da Verdade. Relatório. http://www.cnv.gov.br/images/relatorio _final/Relatorio_Final_CNV_Volume_I_Tomo_I.pdf. Accessed in February 2015.

D’ARAUJO, Maria Celina (2015), Le Congrès et le coup d'État de 1964. La démocratie libérale brésilienne posait-elle un problème institutionnel? In: GREEN, James (ed.). Le coup d'État militaire 50 ans après. Coleção Brésil(s), Éditions de la Maison des Sciences de l’Homme. № 05. pp. 33-53. Paris.

D’ARAUJO, Maria Celina; SOARES, Gláucio Ary D. and CASTRO, Celso (1994), Os anos de chumbo. Rio de Janeiro: Relume Dumará. 326p.

FERREIRA, Jorge and GOMES, Ângela de C. (2014), 1964, o golpe que derrubou um presidente pôs fim ao regime democrático e instituiu a ditadura no Brasil. Rio de Janeiro: Civilização Brasileira. 420p.

FICO, Carlos (2014), o golpe de 1964. Rio de Janeiro: Editora da FGV. 148p.

GALLO, Carlos Arthur and RUBERT, Silvania (eds.) (2014), Entre a memória e o esquecimento, estudos sobre os 50 anos do Golpe Civil-Militar no Brasil. Porto Alegre: Editora Deriva. 348p.

MARKUN, Paulo (2014), Na lei e na marra, 1964-1968. São Paulo: Benvirá. 424p.

MOTTA, Rodrigo Patto Sá (2014a), As universidades e o regime militar. Rio de Janeiro: Zahar. 448p.

MOTTA, Rodrigo Patto Sá (2014b), A modernização autoritária-conservadora nas universidades brasileiras e a influência da cultura política. In: REIS, Daniel Aarão; RIDENTI, Marcelo and MOTTA, Rodrigo Patto Sá (eds.) (2014), A 
ditadura que mudou o Brasil, 50 anos do golpe de 1964. Rio de Janeiro: Zahar. pp. 48-75.

NAPOLITANO, Marcos (2014), 1964, História do regime militar brasileiro. São Paulo: Contexto. 368p.

ORTIZ, Renato (2014). Revisitando o tempo dos militares. In REIS, Daniel Aarão; RIDENTI, Marcelo and MOTTA, Rodrigo Patto Sá (eds.). A ditadura que mudou o Brasil, 50 anos do golpe de 1964. Rio de Janeiro: Zahar. pp. 112-127.

REIS, Daniel Aarão (ed.) (2014a), Modernização, ditadura e democracia, 19602010. Coleção História do Brasil Nação. Rio de Janeiro: Objetiva. 320p.

REIS, Daniel Aarão (2014b). Ditadura e democracia no Brasil. Rio de Janeiro: Zahar. $196 p$.

REIS, Daniel Aarão, RIDENTI, Marcelo and MOTTA, Rodrigo Patto Sá (eds.) (2014), A ditadura que mudou o Brasil, 50 anos do golpe de 1964. Rio de Janeiro: Zahar. $272 \mathrm{p}$.

RIDENTI, Marcelo, (2014). As oposições à ditadura. In: REIS, Daniel Aarão, RIDENTI, Marcelo and MOTTA, Rodrigo Patto Sá (eds.) (2014), A ditadura que mudou o Brasil, 50 anos do golpe de 1964. Rio de Janeiro: Zahar. pp. 30-47.

ROLLEMBERG, Denise and QUADRAT, Samantha Viz (2010), A construção social dos regimes autoritários. Legitimidade, consenso e consentimento no século XX. Rio de Janeiro: Civilização Brasileira. Three volumes. 1240p.

SANTOS, Wanderley Guilherme dos (1962), Quem dará o golpe no Brasil? Cadernos do Povo Brasileiro. Volume 05. Available at http://www.fpabramo.org.br/uploads /quemdaraogolpe.pdf. Accessed in January 2015.

SERRA, José (2014), Cinquenta anos esta noite, o golpe, a ditadura e o exílio. Rio de Janeiro: Record. 266p.

SILVA, Juremir Machado da (2014), 1964 golpe midiático-civil-militar. Porto Alegre: Sulina. 159p.

TAVARES, Flávio (2014), 1964, o golpe. Porto Alegre: L\&PM. 320p.

VILLA, Marco Antonio (2014), Ditadura à brasileira. São Paulo: Leya. 432pp. 